\title{
The Effect of Implementation Quality Assurance and Business Incubators on Entrepreneur Quality and its Impact on SMEs Performance in East Java
}

\author{
Syaiful Arifin, Rudy Wahyono and Tri Wahyuni \\ Faculty Economics and Business \\ University of Merdeka Malang, Indonesia
}

\begin{abstract}
This study examined the implementation of quality assurance and business incubators to quality entrepreneurs and their impact on the performance of SMEs in East Java. The results of this study indicate that the implementation of quality assurance in the implementation of training on the entrepreneurs affect the quality of the implementation of a business incubator entrepreneur and also affect the quality of the entrepreneur in managing its business, so by increasing the quality of the entrepreneur affect the performance of SMEs are getting better in East Java. Respondents in this study involving 100 entrepreneurs of SMEs in East Java. With the proviso noun turnover of USD 50 million and a workforce of at least two people. Of University Merdeka Malang as Education Cleaner has a quality assurance program and the business incubator strives to be a university that can contribute and benefit in helping and developing the performance of SMEs in East Java. With the implementation of quality assurance of the Entrepreneur by insight and direct implementation in the form of learning and training in business, so that the entrepreneur really more qualified. While the business incubator program emphasizes the direct implementation of the business or businesses that directly occupied by the entrepreneur who monitored the process in a business incubator. So that through the implementation of quality assurance and business incubator will be achieved Entrepreneur good quality and will ultimately improve the performance of SMEs.
\end{abstract}

Keywords: Quality Assurance, Business Incubator, Quality of Entrepreneurs, SMEs Performance.

\section{INTRODUCTION}

Small Micro and Medium Enterprises (SMEs) should be recognized as a strategic force and it is important to accelerate regional development, and therefore the growth of Micro, Small and Medium each year has increased (Hasnullah, 2007). Micro, small and puffy (SMEs) are a group effort most can survive when the economic crisis hit the country. The number of small and medium business unit continues to increase, it will be able to open a big job. However, small businesses are still perceived as weak operating performance. The number of SMEs in East Java currently reached 4.2 million SMEs, of which $85.09 \%$ are micro enterprises; $14.19 \%$ are small businesses; $0.57 \%$ medium and only $0.15 \%$ in the form of large-scale enterprises. SME sector efforts have helped economic growth in East Java by donating the regional gross domestic product (GDP) of 53.4\%, equivalent to Rp 415.7 trillion, therefore, the SME sector has a strategic role for the economy in East Java. SME sector has a business pattern that is unique, because more is done within the scope of the informal sector, where $30 \%$ SME meet the criteria are eligible (feasible) and bankable, while the remaining $70 \%$ only meet these criteria are eligible (feasible) but not yet bankable.

Being an entrepreneur is not easy, the magnitude of the risk to venture into one of the biggest obstacles for people to start a business. Even for fear of the risks, many people who stopped along the way and to make matters worse many of those who quit before they try. They prefer the safety zone without thinking about the magnitude of risk of loss. No wonder if our society is more interested in becoming a civil servant or an employee in a company compared to being an entrepreneur. This proves that not all people have the entrepreneurial spirit.

Basically conducted by the business incubator is a part of the program as a partnership to develop the business together, with the aim of making the business into a real business and develop in accordance with the vision of the company. One way in which the Government to foster and develop small entrepreneurs is through business and technology incubator program. Generally incubator in Indonesia was formed with the purpose of:

a. Develop new businesses and small businesses as potential independent business, so it is able to successfully deal with global mapun local competition. 
b. Promoting the spirit of entrepreneurship to include private companies are expected to contribute to the market economy system.

c. The process of technology transfer and the commercialization of the results of research and technology business development from experts, inventors and researchers at universities.

d. Open up alternative opportunities through the development of new companies.

e. Applications in industrial technology commercially through study and review of time-consuming and relatively low cost. Economic experts believe that the Incubator is one of the effective means in menumbuhkembangan new technology-based entrepreneurship. In the implementation of its activities, Incubator intermediation function and conduct a strengthening of the tenant / potential new entrepreneurs and products / services that will be developed through the innovative provision of services as a means of business development, access to capital, training, assistance, and guidance entrepreneurship. This effort is expected as a step in the alignments in the SMEs / SME / SMEINDONESIA.

Recognizing the importance to keep alive and develop a business incubator program in terms of promoting economic growth and competitiveness of the nation, it is necessary to be realized a national movement with concrete support legislation and government regulations more or implementation.

This study aimed to describe Quality Assurance, Business Incubator, Quality of Entrepreneurs, SMEs Performance; analyze the influence of Quality Assurance and Quality Business Incubator of the Entrepreneur; analyze the influence of Quality Assurance and Business Incubator on SMEs Performance; analyze the effect of quality on the Performance Entrepreneur SMEs; and analyze the influence of Quality Assurance and Business Incubator of the SMEs performance through Quality of Entrepreneur.

\section{LITERATURE REVIEW}

\subsection{Quality Assurance}

Implementation of quality assurance is a concept improvements are made continuously involving all employees in every level of the organization to achieve excellent quality in all aspects of the organization, through the process of education management (Dipletro, 2003). There are four areas of application quality assurance (JF Hebert et.al, 2005), which first involves the use of total quality management in improving administrative functions and universities. This application relates to a decision-making perspective. In this case both the rector and the university administration managers need to make the decision to support the achievement of long-term strategic objectives. It is also to emphasize the managerial role, which is to meet customer demand in the future.

Quality assurance is the most powerful tool to improve the effectiveness of education. Quality assurance as a key principle in which the holder of the main roles of education, such as teachers, principals and stakeholders: students, parents, school administrative staff, government / foundations, and community, is responsible for enhancing school performance. To that end, the center of the school is the quality assurance process of self-evaluation and development planning (Birzea et al, 2005).

\subsection{Business incubator}

Business incubator is a company / institution that provides a program designed to foster and accelerate the successful development of the business through a series of programs of capital followed by partnership support / guidance elements other business with the aim of making the business into companies that are profitable, have the organizational and financial right, as well as being a sustainable company, to finally have a positive impact on society.

\subsection{Quality Entrepreneur}

An entrepreneur is an entrepreneur who has a wide range of the company but taking a great risk to become entrepreneurs. Not all entrepreneurs are entrepreneurs and not all entrepreneurs have the same quality. Entrepreneurs not a person who does not know fear. They created a priority so beat the fear of failure, frustration, boredom, dissatisfaction and fear of success.

Entrepreneur (entrepreneur) is not a super-human or human magic. They are just ordinary people but they are different from most people. What differentiates them are entrepreneurs with vision, determination, persistence is strong in terms of development and change to something. Additionally entrepreneur has positive characteristics that were not owned by the average person.

\subsection{SMEs performance}

Performance or performasi is work that can be achieved by a person or group of people in the organization, in accordance with the authority and responsibilities of each in order to achieve organizational goals (Suryadi, 2009). If the individual performance is good, it is most likely performance of the company or organization will be good. A company's performance is the result of many individual decisions are made constantly by the management (Helfert, 1996). Baswir (2010) adds that there are four main causes of low performance of micro, small and medium enterprises (SMEs) in Indonesia, namely: 1) Nearly 60\% of small businesses still using traditional technologies; 2) The market share tends to decline because of a lack of capital, technology and managerial weakness; 3) Most small businesses are not able to meet the administrative requirements for assistance from the Bank; 4) The level of dependence on government facilities tend to be very large.

\section{RESEARCH METHODS}

\subsection{Types of research}

This study is the explanation (explanatory research). Explanatory research is intended to clarify or explain a phenomenon, explain relationships, examine the influence between variables. 


\subsection{Operational Definition of Variables}

a. Quality assurance

Quality Assurance is all planned and systematic actions implemented and demonstrated to provide adequate confidence that the product will satisfy the needs of a particular quality. Quality assurance indicators used in this study are: Aspects of the management system and technical requirements

b. Business incubator

Business incubator is a company or institution that provides a program designed to foster and accelerate the successful development of the business through a series of capital program, followed by support coaching partnership or other business elements with the aim of making the business into the company. Indicators of business incubators used in this study are: gain new business, job creation, the economic cycle, the failure rate of new business development and the ability of an investment fund.

c. Quality Entrepreneur

Entrepreneur quality is entrepreneurial activity characterized by clever or talented to identify new products, determine how new production, operations management arrange for the procurement of new products, market, and manage the capital operations. Entrepreneurial quality indicators used in this study are: the orientation of the strategy-driven perception of opportunities, commitment to the opportunities, the commitment of resources, control of resources and realistic vision.

d. SMEs performance

SMEs performance is a measure of the success of SMEs in a certain period. Performance indicators consist of four indicators; financial performance and non-financial performance.

\subsection{Data analysis method}

This research uses descriptive analysis and inferential statistical analysis using the statistical method of Structural Equation Modeling (SEM) with AMOS software program 18. Testing the overall model (full model structural) in the SEM analysis based on the evaluation criteria of goodness of fit on the model analyzed by kriteria- recommended criteria.

\section{RESULTS AND DISCUSSION}

\subsection{Structural Equation Model Test Results}

The test results prove SEM assuming normal distribution of data, there are no outliers and multicollinearity problem. Observation data already qualified to be tested in the model equations researchers structures built with the help of 18 AMOS program (Analysis Moment of Structure). The test results of modeling overall appears in Figure 1.

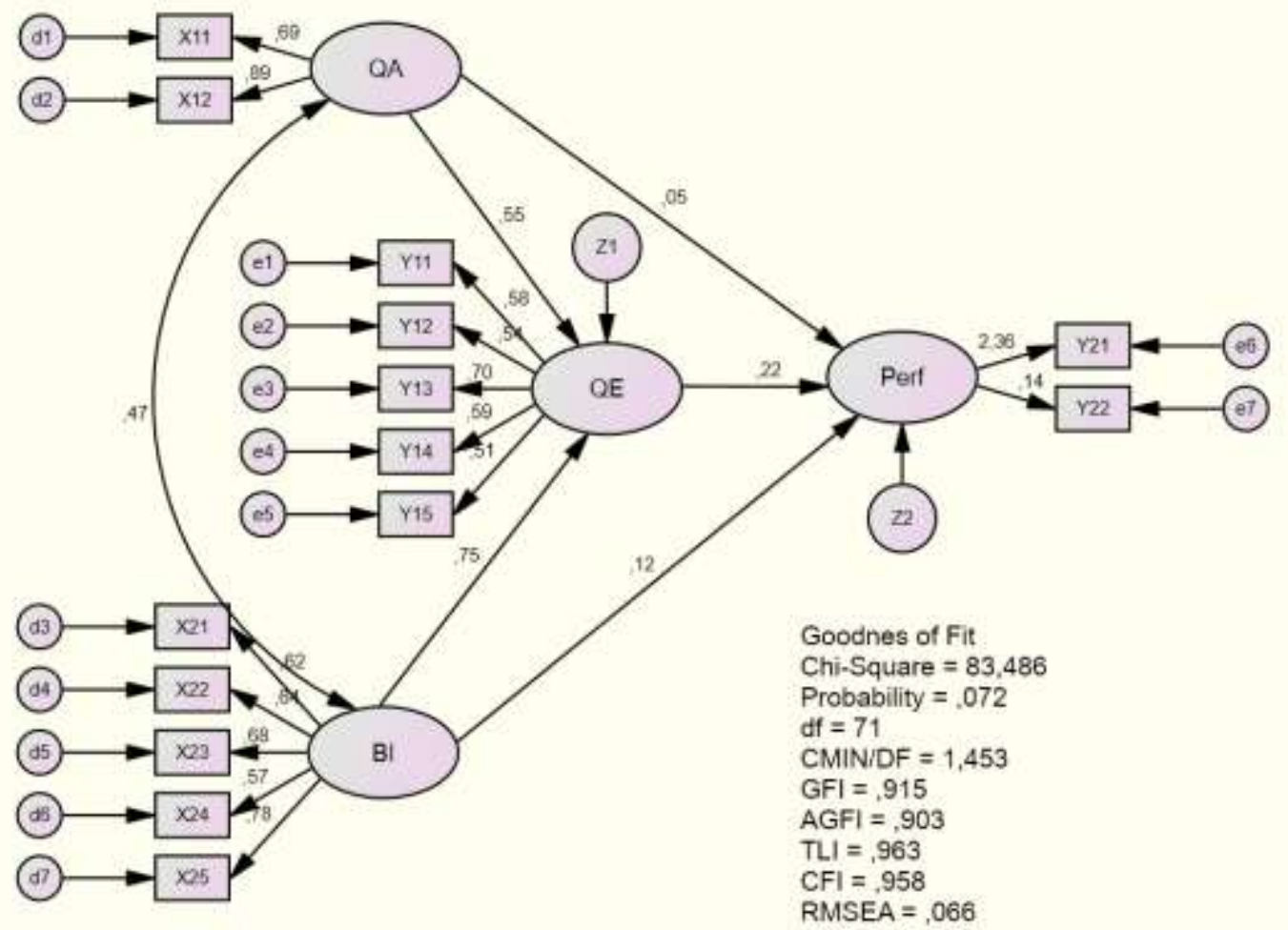

Figure 1. Structural Equation Modeling Research

Rejection or acceptance of Structural Equation Model as an analytical tool appears on the value of goodness of fit reindexs produced. The acceptance criteria of structural equation model will be compared with the cut-off suggested. Evaluation of Goodness of fit reindexs values are presented in Table 1. 
International Journal of Advances in Scientific Research and Engineering (ijasre), Vol 5 (10), October-2019

Table 1. Evaluation of Goodness of Fit Structural Equation Modeling

\begin{tabular}{lccc}
\hline \multicolumn{1}{c}{ Goodness of fit indices } & Cut-off value & Result & Status \\
\hline Chi-square (df =71) & 91.67 & 83.486 & Good \\
Chi-Square Probability & $\geq 0.05$ & 0,072 & Good \\
CMIN / DF & $\leq 2.00$ & 1,453 & Good \\
RMSEA & $\leq 0.08$ & 0,066 & Good \\
GFI & $\geq 0.90$ & 0.915 & Good \\
AGFI & $\geq 0.90$ & .903 & Good \\
TLI & $\geq 0.95$ & 0.963 & Good \\
CFI & $\geq 0.95$ & 0.958 & Good \\
\hline
\end{tabular}

Sources: Primary data is processed.

Based on the evaluation criteria of goodness of fit in Table 1, show that the overall evaluation models already meet the recommended, Thus ith structural equation model was built to become a model of analysis to prove the hypothesis and research findings.

\subsection{Data Analysis}

In order to determine the effect of the implementation of quality assurance and business incubators to quality entrepreneurs and their impact on the performance of SMEs in East Java can be seen in the following table.

Table 2. Causality Test Research Variables

\begin{tabular}{|c|c|c|c|c|c|c|}
\hline \multicolumn{3}{|c|}{ Variables } & \multicolumn{4}{|c|}{ Regression Coefficients } \\
\hline \multirow{2}{*}{ Exogenous } & \multirow{2}{*}{ Mediation } & \multirow{2}{*}{ Endogenous } & \multicolumn{2}{|c|}{ Direct Effect } & \multirow{2}{*}{$\begin{array}{c}\text { Indirect } \\
\text { Effect }\end{array}$} & \multirow{2}{*}{ Total } \\
\hline & & & Coefficient & P value & & \\
\hline Quality Assurance & Quality Enterprenuer & - & .750 & $0,000 *$ & - & - \\
\hline business incubator & Quality Enterprenuer & - & .551 & $0,000 *$ & - & - \\
\hline Quality Assurance & - & SMEs performance & 0.052 & $0,045 *$ & - & - \\
\hline business incubator & - & SMEs performance & 0.121 & $0,017 *$ & - & - \\
\hline- & Quality Enterprenuer & SMEs performance & 0.222 & $0,041 *$ & - & - \\
\hline Quality Assurance & Quality Enterprenuer & SMEs performance & 0.052 & - & 0,012 & 0,064 \\
\hline business incubator & Quality Enterprenuer & SMEs performance & 0.121 & - & 0,027 & 0.148 \\
\hline
\end{tabular}

* Significant at $\alpha 5 \%$.

The test results prove that the quality assurance significant effect on the quality of the entrepreneurs because the probability was 0.000 (less than 0.05). Direction and magnitude of the coefficient of direct influence (standardized direct effect) amounted to 0.750 , and to test the significance of using a value of $p<0.05$. These test results prove that the Quality Assurance positive and significant impact on the quality of entrepreneurs.

Business Incubator significant effect on the quality of entrepreneurs because the probability was 0.000 (less than 0.05 ). Direction and magnitude of the coefficient of direct influence (standardized direct effect) amounted to 0.551 and to test the significance of using a value of $\mathrm{p}<0.05$. These test results prove that the business incubator positive and significant impact on quality of entrepreneurs.

The test results prove that the quality assurance significant effect on the performance of SMEs due to the probability obtained at 0,045 (less than 0.05). The direction and magnitude of the coefficient of direct influence (standardized direct effect) amounted to 0.052, and to test the significance of using a value of $\mathrm{p}<0.05$. These test results prove that the Quality Assurance positive and significant effect on the performance of SMEs.

Business Incubator significant effect on the performance of SMEs due to the probability obtained at 0,017 (less than 0.05). The direction and magnitude of the coefficient of direct influence (standardized direct effect) amounted to 0.121 , and to test the significance of using a value of $\mathrm{p}<0.05$. These test results prove that the business incubator positive and significant effect on the performance of SMEs.

The test results prove that the quality of entrepreneurs significant effect on the performance of SMEs due to the probability obtained at 0,041 (less than 0.05 ). The direction and magnitude of the coefficient of direct influence (standardized direct effect) amounted to 0.222 , and to test the significance of using a value of $p<0.05$. The test results showed that the quality of entrepreneurs, positive and significant effect on the performance of SMEs.

Results of analysis Quality assurance influence on SMEs performance through Quality of entrepreneurs showed that the total effect is greater than 0,064 direct effect of 0.052 , so the quality of entrepreneurs proven as an intervening variable that mediates Quality assurance on the performance of SMEs. Business Incubator of the SMEs performance through Quality of entrepreneurs showed that the total effect 0.148 is greater than 0.121 direct effect, so that the quality of entrepreneurs as an intervening $\mathrm{v}$ ariable that mediates the business incubator on the performance of SMEs. 


\section{DISCUSSION}

\subsection{Influence on the Quality Assurance Quality Entrepreneur}

Quality assurance affect the quality of the entrepreneur, this suggests that quality assurance is a factor that plays a role in improving the quality of the entrepreneur. Quality Assurance as part of the quality system is improved quality-based prevention and problem solving. Improving quality is a process of measuring the degree of perfection of service compared with the standard and systematic action and continuous improvement, to achieve optimal service quality standards and available resources. QA usually requires continuous evaluation and is usually used as a tool for management. As the opinion and Gryna Juran (2008), Quality Assurance is an activity to provide the evidence to build confidence that the quality function effectively. Forms Quality Assurance consisting of 2, namely: Individual-based and team-based Activity program. Individual wherein committed against individuals based program, through monitoring / monitoring (tool-shaped document or recording), assessment (internal audit) and control (correction). While team-based activity is a quality assessment activities of the team. Moreover, the purpose of holding the Quality Assurance This is in order to satisfy the various parties involved in it, so that they can successfully achieve their goals. Quality assurance is an integral part in shaping the quality of the products and services of an organization or company. Quality assurance mechanisms used also must be able to stop the changes that judge these changes towards a decline or deterioration. Quality Assurance in activities covered there in quality control and inspection of the quality where both the activity is part of an overall commitment to quality. Yet Yag holds Quality Assurance department does not charge for checking other parts of the work performed. But QA helps the other parts so that it can control the application of the applicable procedures correctly, so as to achieve improvements in efficiency, produktivitns, and profitability. Expected through the Quality Assurance is doing all the work properly at any time efficiently that is associated with the services associated with the process in accordance with the minimum service standards or quality standards (SOP), and effectively linked to the achievement of objectives in the form of outputs and outcomes (effects) the expected or planned. Entrepreneurs face all sorts of obstacles as a whip so that their businesses grow. The greatest asset of an entrepreneur is the ability to work through the obstacles. A successful entrepreneur is an entrepreneur keen to see opportunities, discover and utilize resources, creative, innovative, and tolerate uncertainty so that entrepreneurs can grow and quality and healthy competition.

\subsection{Influence on the Quality of Entrepreneur Business Incubator}

Business incubator significant effect on the quality of the entrepreneur, which means that the better the business incubator program can improve the quality enterprenuer. Business Incubator was instrumental in the effort to provide business expertise to the tenants (small businesses). A businessman to be able to achieve success in the business world must have sufficient knowledge and skills in the business sector. Based on this a business incubator should provide knowledge and skills to the tenantnya. Giving skills and knowledge is very helpful in creating self-reliance of tenants especially when they have to leave the business incubator. Business incubators can be regarded as a place that provides facilities for the accelerated growth of self-employment through infrastructure owned accordance with the base of his competency. By utilizing the facilities and services provided by the incubator, the service user (tenant) can improve the weak sides of the aspects of entrepreneurship. Development of business incubators associated very much with the development of micro, small and medium enterprises / SMEs (micro, small and medium enterprises / SME's), because the grower economics in general initiated by the presence of micro and small enterprises. Micro and small entrepreneurs constitute the largest part of the business in Indonesia, so that quantitatively this group has a very important role and strategic. The presence of business incubators can have 2 (two) role, namely:

In the incubator there are three types of programs that could be implemented by employers or prospective employers. First, the incubator technical technology incubator, namely (1) the granting of skill knowledge of production techniques both from design to finishing, (2) matters relating to aspects of business and management business incubator, in this program participants will gain the knowledge of management, financial, and product marketing strategy and (3) the so-called regional development incubator, a program of development of a particular region that already has a thriving business types. Business Incubator strives to help entrepreneurs develop business skills so that they can thrive in the community by providing services and supports that help enhance their natural talents and abilities so that they can develop their potential. Thus the business incubator into an important link that connects between employers mainly oriented technology (including who has new ideas) with the institutions that offer services and products they needed in the development efforts.

\section{CONCLUSIONS AND RECOMMENDATIONS}

\subsection{Conclusion}

Based on the results of data analysis showed that the quality assurance aspect of the system is formed by the management and technical requirements, the main contribution is the establishment of a quality assurance management system aspects. Business incubator formed by the accretion of new businesses, job creation, the economic cycle, the failure rate of new business development, and the ability of an investment fund. The main contribution is the establishment of business incubators gain new business. The quality of entrepreneurs formed from the orientation of strategy-driven perception of opportunities, commitment to the opportunities, the commitment of resources, control of resources and realistic vision. The main contribution is a commitment to the quality of the entrepreneur opportunities. Quality assurance significant effect on the quality of the entrepreneur.

\subsection{Recommendation}

Entrepreneurs need to increase their creativity and hone their potential by adding insight, experience, and training to develop their business so that they can compete and expand the market so that the business carried out is better developed and business development, profit development, workforce development, and management development are increasingly professional. 
In addition, entrepreneurs must always follow the development of national and global business, improve the ability and skills in information technology so as not to be outdated in a world that is increasingly globalized, especially in the face of MEA, AFTA so that their businesses in UMKM excel in competition.

\section{REFERENCES}

1. Baswir, Revrisond. 2010. Agenda Ekonomi Kerakyatan. Yogyakarta: Pustaka Pelajar.

2. Birzea, Cesar, et al. 2005. Tools for Quality Assurance of Education for Democratic Citizenships in Schools. United Nations Educational, Scientific and Cultural Organizations.

3. Dipletro, TQM: Evaluation, Scope and Strategic Significance for Management Development. Journal of Management Development, 2003 12: 11-18.

4. Hasanullah. 2007. The role of Bank Indonesia PPUK In granting KUK by banks in Indonesia. Master of Management Journal. No. 26, Jakarta, IPWI Publisher Agency.

5. JF Hebert et.al, 2005. The Implementing of Total Quality Management in Higher Education. University of New England: Center for Higher Education Management and Policy.

6. Suryadi, Ace. 2009. Education Human Resources Investment and Development. Jakarta: Balai Pustaka.

7. Omar, Hussein. 2003. Evaluation of Company Performance, PT. Gramedia Pustaka Utama, Jakarta. 